\title{
Establishment Arena of a Multicultural Society in Lasem
}

\author{
Jayusman $^{1}$ \\ $\left\{\right.$ jjayusman@gmail.com $\left.{ }^{1}\right\}$ \\ Universitas Negeri Semarang, Indonesia ${ }^{1}$
}

\begin{abstract}
Racial problems are still not dimmed in Indonesia. One that is difficult to resolve is a matter of ethnic prejudice. Especially the most striking and historical background is the relationship between the Javanese-Chinese community. This study aims to reveal the arena of the formation of a multicultural society in Lasem, this can be a reference model for people with heterogeneous populations to foster diversity and tolerance. This research was carried out using qualitative methods with ethnographic design. The data source of this study is divided into 2 categories, namely Chinese families and Javanese families in Lasem, Rembang Regency, Central Java, Indonesia. The results of this study are: 1) the Chinese community in Lasem has merged into the social life of the Javanese community through daily activities that involve the cooperation of both such as sewing, clean the village, batik, and religious activities; 2) the environment forming a multicultural society in Lasem is quite unique because the settlements of Chinese and Javanese people live side by side, in contrast to the cases in the Chinatowns of Semarang, Pekalongan, Jakarta, Solo, Pekalongan, Tegal, and other former colonial cities; and 3) the Chinese community in Lasem realizes the importance of tolerating life and discarding prejudice against Javanese society, besides that Javanese people also think that it requires solid cooperation to build social harmony in Lasem. The implication of this study is the need for habitus and an environment that is side by side full of awareness and understanding of peaceful life, it can be started by removing prejudices and stereotypes towards certain ethnic groups.
\end{abstract}

Keywords: Arena, Environment, Multicultural, Lasem

\section{Introduction}

Racial problems still haunt Indonesia, the most striking and can still be observed to date is the prejudice between ethnic Chinese-Javanese. The cultural mix between Chinese and indigenous Lasem formed in a social structure that needed each other, this became the embryo of the formation of a multicultural society. Although the New Order state had limited the movement of ethnic Chinese communities in a discriminatory manner, the Lasem community remained harmonious in the maintained conditions of multiculturality [1], [2]. Multiculturalism itself becomes a determinant in the creation of development [3] [4]. Multiculturalism in Lasem becomes social capital to create a solid and harmonious society.

This study aims to reveal the arena of the formation of a multicultural society in Lasem. Arena according to Bordieau is a place for the community to carry out daily social practices [5]. This activity reflects the social conditions of the community. The contribution of this research is in the form of contributing ideas about peace and harmonization of society. 


\section{Research Method}

This research was conducted using qualitative methods with a realist ethnographic framework [6]. The socio-cultural object studied is the Lasem community, focusing on the Chinese and Javanese people in social and cultural life. The informants of this study were divided into two categories, namely Chinese families and Javanese families. Researchers have been united and become part of the socio-cultural object for more than two years. Therefore, researchers observe people's lives directly, from social interactions to cultural interactions [6]. The data obtained was checked for accuracy through triangulation techniques [7]. Data analysis of this study used an interactive model [8].

\section{Result and Discussion}

\subsection{Arrival of the Chinese in Lasem}

Chinese in Indonesia are Chinese-born immigrants or according to the male line. However, as a result of mixed marriages and assimilation in some regions of Indonesia, we can no longer ensure between Chinese and non-Chinese people, based on the simplest racial criteria. In Indonesia, a Chinese descent is called a Chinese if he acts as a member of the Chinese community, and identifies himself with the Chinese community [9]-[11]. The only reliable feature of culture, from self-identification as Chinese and attachment to the Chinese community system, is the use of Chinese surnames.

The formation of the Chinese community in Lasem through a long historical process. Beginning with trade relations between the Chinese kingdom and the kingdoms in Indonesia around the beginning of the $5^{\text {th }}$ century AD [12]-[14]. The Chinese used their Jung boats from the southeastern part of China [14], while the Chinese population growth in Indonesia subsequently was closely related to its role in the economic field. During the reign of Wijayabadra a Ming dynasty fleet from China led by Admiral Haji Cheng Ho landed in the area of Tuban, near Lasem, on his third trip. The landing of the Cheng Ho fleet occurred in 1335 Saka (1413 AD) [1], [10], [15]. It was at that time that Bi Nang Un, a Champa who served as one of the ship's masters from the Marine Fleet Admiral Cheng Ho, was interested in settling in Lasem Earth [9], [16].

The arrival of Chinese in Java, especially in Lasem and several other places in the region gave birth to new cultures [12], [17]. This culture is the essence of Chinese customs which was later adopted into regional customs that did not fade from the Chinese culture itself. The Chinese community in the Java region, especially in Lasem Subdistrict, is more diffuse compared to the European community [18]. This is influenced by good communication from local communities with the Chinese community themselves.

The relationship between local indigenous residents and immigrant Chinese in Lasem has indeed been established for a long time. The harmony of their relationship can be seen from existing historical relics, such as the number of temples and mosques which are symbols of places of worship for Chinese Muslims as well as Confucianism who still stand firm to this day [19], [20], side by side with religious facilities others such as the Javanese Mosque and the church. 


\subsection{Lasem Environment: Arena for Establishment of a Multicultural Society}

The long history of the existence of the Chinese community in Lasem gives color and uniqueness to the shape and structure of the city of Lasem. Likewise the adaptation of the Lasem Chinese community to the local population as well as the population of other ethnicities has given color to the culture and activities of the Chinese people in particular and the Lasem community in general. This paper examines the development of Chinese culture in Lasem which has a uniqueness that can be used as regional identity [21].

As a royal city, Lasem was originally a fairly busy trading city. The development of Lasem was greatly supported by the authorities who succeeded in creating conditions that supported the security and comfort of trade activities [22]. In addition, the geographical conditions which are very strategic are located between the two provincial capitals and have adequate rivers for commercial transportation facilities to the interior, making Lasem the main destination for immigrants to make a living and become a choice as a place to settle.

At the beginning of its development, which is around the XIV Century Lasem has two city centers which are the center of activity, namely the palace as the center of government and Chinatown (In Indonesia: Pecinan) which is located on the edge of Lasem as the center of commerce. Chinatown as a trading area also functions as a settlement of Chinese people [18]. The development of Chinese settlements was followed by the construction of temples as a means of worshiping and worshiping ancestors and T'ian, as well as for social and cultural activities.

Chinatowns and temples are two inseparable things in the lives of Chinese people in Indonesia. Chinatown is the name for a residential area of Chinese people with distinctive culture and traditions from their home countries. Kelenteng is a building for worship and worship of deities in Tri Dharma (Tao-Confucius-Buddha) beliefs or religions. Aside from being a place of worship, the temple functions as a medium of expression to display the existence of Chinese culture [23], [24]. So in general it can be said that, at the beginning of the formation of the Chinatown area to date, the identity/image of the Chinatown is the temples found in the region. Vice versa, the location of the temple stands around the Chinese settlement (Chinatown).

The mention of temples for buildings where Chinese people worship is difficult to trace. Some researchers say that, the designation of the temple comes from the sound of small and large bells used as worship equipment, which reads "klinting-klinting" or "klonteng-klonteng" [25]. Some argue that the temple comes from the word "Yin Ting" or "Guan Yin Ting", which means the place of worship of Goddess Kwan Im.

The Chinese community in Lasem has joined the social life of the Javanese community through daily activities that involve good cooperation such as sewing, cleaning the village, batik, and religious activities. The social activity was an important factor besides Lasem's environment which was built harmoniously without prejudice towards any ethnic group. The Lasem community, both Chinese and Javanese, have realized the importance of living in harmony for the common good. In harmony with the opinion of Banks that multicultural society upholds common interests rather than interests of an ethnic nature [3], [26]. Local aspects such as those in Lasem, and folklore that existed there became the social capital of the community to develop more inclusive cultural communication [27]. Folklore can be a heroic tale that tells the grandmother's collaboration between the ancestors of the two ethnic groups, to build an inclusive and open society so that it can be taught or socialized directly in the community [28]. 
The Chinese community in Indonesia in general and in Lasem in particular, in building settlements and other buildings adheres to the principles of spatial management in harmony with the surrounding environment. The concept of spatial structure in the Chinese tradition is feng shui or hong shui. Feng is wind and shui is water. So the notion of feng shui is the concept of spatial regulation that harmonizes environmental conditions with the flow of air (wind) and water around us [29]. We can see the background of the application of feng shui to the Chinatown spatial layout on elements related to natural structures that have been formed and become part of the area such as rivers, land or locations and building elements represented by residential buildings, shop buildings, temple and road building.

The Chinese and Javanese communities do not make the issue of ethnicity a benchmark in building settlements. There are many churches, mosques, and adjacent temples in Lasem, considering that the Chinese Muslim community is quite numerous and easily found in Lasem [30], [31]. This kind of harmony is a sign that the Lasem environment is built on harmony. In addition, the houses of the Lasem community are also side by side and neat, there are no special barriers between the Chinese and Javanese people, which distinguishes them only in terms of architecture and home decoration.

In Lasem there are three temples which are located adjacent to the Lasem river, namely the An Kiong Cu temple located on Dasun Street 19 Lasem, Gie Yong Bio temple, located on Babagan Street 7 Lasem and the temple of Poo An Bio, located on Karangturi Street VII/13, Lasem [10], [32]. Seeing the names of temples containing the words Bio and Kiong, it can be mentioned that the temples in Lasem are Taoist or Confucius temples and clan temples. The temples are also distinguished by function and purpose of establishment, namely public temples and clan temples.

The location of the temple which is adjacent to the river contains multi meanings, namely: 1) In Chinese public trust, water is an important element. Water in this sense is naturally formed water, such as rivers, lakes, sea water, waterfalls and so on. The natural water element around the Chinatown is the Lasem River, which the Chinese community also believes is related to feng shui. In the concept of harmonious feng shui water will create good energy or chi, which will bring good luck to the people around it; 2) Rivers at that time were very effective means of water transportation for trade routes and distribution of goods from the interior to the city and vice versa. The area around the river eventually became a bustling commercial city and as a residential community of China [17], [22].

The existence of temples in Lasem does not only reflect the spiritual activities and beliefs of the Chinese people in Lasem, but also reflects all the cultural, social, economic and political activities of the Chinese community [33]. The cultural dynamics of Chinese society in Lasem leave a trail of beauty that enriches Indonesian culture as a whole, both cultural and nonphysical.

Koh Yanse, a citizen of Chinese descent in Lasem, said that the existence of the Chinese community in Lasem was well received and that even today the mixing between the two is not new. Marriage that happened between the Chinese community and the Javanese community became a mirror that Lasem had a fairly strong harmonization and became a big capital in building a multicultural society (interview 18 April 2019). Examples of the marriage took place in the Suparjo (Javanese) and Haryanto (Muslim Chinese) families, both of whom agreed that the question of ethnicity was no longer a problem in community life (interview April 19, 2019). The experience of their ancestors became a valuable asset for living in harmony [34].

The pattern of residence of the Lasem community is not limited to ethnicity, unlike the cases of Semarang, Jakarta, Solo, Pekalongan, and Tegal, where Chinese people live in closed 
Chinatown, in Lasem Chinese and Javanese settlements blend into one, although still called Chinatown but Lasem settlement more inclusive. This is a valuable capital for the formation of a multicultural society, the sign that Lasem's environment is quite friendly to any ethnic group. Lasem's environment is not an environment built on a discriminatory spirit [17], [25], [35]. Parijan, Haryo, and Suwanda give the opinion that the Lasem community cannot be distinguished from the people in other cities. The Lasem neighborhood is an environment built for all, not only Javanese and Chinese but Arabic, Madurese, Bugis can also live in Lasem (interview April 15, 2019). The sign is that the Lasem community does have a unique characteristic in maintaining peace. This is proof that Lasem's environment is one of the special assets of Java.

Javanese and Chinese people are the largest in Lasem, both of whom share a perspective on pluralism. Javanese people see pluralism as a capital to build a peaceful life, while Chinese people see pluralism as a valuable capital to continue life (economic perspective). Pluralism for both of them has an important meaning for life, the difference in perspective does not necessarily make the two ethnicities move away or contradict each other. On the contrary, this difference makes ethnicity in Lasem stronger. This seems different from the conditions in other cities, such as Semarang, Surabaya and Jakarta. In the city, this is consistent with the findings of Coppel and Purdey, who showed very strong anti-Chinese sentiment in these cities [36], [37]. This study reinforces Suryadinata's opinion, which explains that not all regions in Indonesia have anti-Chinese sentiments [33]. Lasem is proof that Chinese-Javanese relations in Indonesia are not always bad, in that region the relations between the two are quite productive and run positively in supporting peace and state development.

\section{Conclusion}

The plurality of the Lasem community and the friendly environment for all are the main characteristics of the Lasem community known by the wider community. The Lasem environment is an arena for the formation of an ideal multicultural society, habituation through joint work and sharing with one another to become a valuable capital of harmonization of the Lasem community can be created. As an arena for the formation of successful multicultural communities, Lasem deserves to be an example for cities with other heterogeneous populations. Lasem can be a model for other regional governments who want to build a harmonious plural society. One of the recommendations of this research is the importance of teaching local potential for students from elementary school to university level. It becomes a long-term investment for the formation of a multicultural society that has an open mindset and can accept differences.

\section{Acknowledgement}

This paper is part of results of a dissertation study of Social Studies Doctoral Program at the Graduate School of Universitas Negeri Semarang. This paper is dedicated to the Research and Community Service Institute of Semarang State University, which has contributed funding for the completion of this research. 


\section{References}

[1] T. M. P. Astuti, E. Kurniawan, and M. Syifauddin, "Lasem 'The City Of Tolerance': A Role Model Of Harmonious Multicultural Life To Develop Tolerance In Indonesia," in International Conference on Rural Studies in Asia (ICoRSIA 2018), 2019.

[2] T. J. Lan, "Munawir Aziz, Lasem kota Tiongkok kecil; Interaksi Tionghoa, Arab, dan Jawa dalam silang budaya pesisiran. Yogyakarta: Ombak, 2014, 212 pp. ISBN: 9786022581666. Price: IDR 50,000 (soft cover).,"Wacana, vol. 16, no. 2, pp. 516$518,2015$.

[3] J. A. Banks, Educating Citizens in a Multicultural Society. Multicultural Education Series. ERIC, 1997.

[4] W. Wasino, "Indonesia: from Pluralism to Multiculturalism," Paramita Hist. Stud. J., vol. 23, no. 2, 2013.

[5] P. Bourdieu, "Structures, habitus, practices," Log. Pract., pp. 52-65, 1990.

[6] J. Clifford and G. E. Marcus, Writing culture: The poetics and politics of ethnography. Univ of California Press, 1986.

[7] R. Heale and D. Forbes, "Understanding triangulation in research," Evid. Based Nurs., vol. 16, no. 4, pp. 98-98, 2013.

[8] M. B. Miles, A. M. Huberman, M. A. Huberman, and M. Huberman, Qualitative data analysis: An expanded sourcebook. sage, 1994.

[9] M. Budianta, "The dragon dance: Shifting meanings of Chineseness in Indonesia," in Asian and Pacific Cosmopolitans, Springer, 2007, pp. 169-189.

[10] L. Suryadinata, China and the ASEAN states: the ethnic Chinese dimension. Marshall Cavendish International, 2005.

[11] K. J. Boroń, J. W. Mietelski, K. Lipka, P. Gaca, and M. Jasińska, "Radionuclides in raised bogs: a case study of Bór za Lasem," J. Environ. Monit., vol. 3, no. 3, pp. 324329, 2001.

[12] L. Suryadinata, Peranakan Chinese Politics in Java, 1917-1942. Marshall Cavendish International, 2005.

[13] H. H. Ong, "Chinese capitalism in Dutch Java," Thugs Curtain Thief Sugar Lord Power Polit. Cult. Colon. Java Jkt. Metaf. Publ., 1989.

[14] W. Gungwu, "Chinese history paradigms," Asian Ethn., vol. 10, no. 3, pp. 201-216, 2009.

[15] L. Suryadinata, Ethnic Chinese as Southeast Asians. Institute of Southeast Asian Studies, 1997.

[16] D. Raybeck, "Chinese patterns of adaptation in Southeast Asia," Chin. Southeast Asia, vol. 2, pp. 15-33, 1983.

[17] M. C. Hoadley, "Javanese, Peranakan, and Chinese elites in Cirebon: changing ethnic boundaries," J. Asian Stud., vol. 47, no. 3, pp. 503-517, 1988.

[18] J. Rush, "Placing the Chinese in Java on the Eve of the Twentieth Century," Indonesia, pp. 13-24, 1991.

[19] H. J. de Graaf and T. G. T. Pigeaud, Cina Muslim di Jawa abad XV dan XVI antara historistas dan mitos. Tiara Wacana, 1998.

[20] S. P. Morgan, S. Stash, H. L. Smith, and K. O. Mason, "Muslim and non-Muslim differences in female autonomy and fertility: evidence from four Asian countries," Popul. Dev. Rev., vol. 28, no. 3, pp. 515-537, 2002.

[21] D. C. Gladney, Muslim Chinese: ethnic nationalism in the People's Republic. Harvard 
Univ Asia Center, 1996.

[22] A. H. Keane, "On the relations of the Indo-Chinese and Inter-Oceanic races and languages,” J. Anthropol. Inst. G. B. Irel., vol. 9, pp. 254-289, 1880.

[23] L. Fan, "International influence and local response: Understanding community involvement in urban heritage conservation in China," Int. J. Herit. Stud., vol. 20, no. 6, pp. 651-662, 2014.

[24] M. F. Rademakers, "Market organization in Indonesia: Javanese and Chinese family business in the Jamu industry," Organ. Stud., vol. 19, no. 6, pp. 1005-1027, 1998.

[25] T. J. Lan, "Munawir Aziz, Lasem kota Tiongkok kecil; Interaksi Tionghoa, Arab, dan Jawa dalam silang budaya pesisiran. Yogyakarta: Ombak, 2014, 212 pp. ISBN: 9786022581666. Price: IDR 50,000 (soft cover).," Wacana, vol. 16, no. 2, pp. 516$518,2015$.

[26] J. A. Banks, "Teaching strategies for ethnic studies.," 1975.

[27] R. Romadi and G. F. Kurniawan, "Pembelajaran Sejarah Lokal Berbasis Folklore Untuk Menanamkan Nilai Kearifan Lokal Kepada Siswa," Sej. Dan Budaya J. Sej. Budaya Dan Pengajarannya, vol. 11, no. 1, pp. 79-94, 2017.

[28] S. Kartodirdjo, Modern Indonesia, tradition \& transformation: A socio-historical perspective. Gadjah Mada University Press, 1984.

[29] O. Bruun, "An introduction to feng shui," 2008.

[30] P. Carey, "Changing javanese perceptions of the Chinese communities in central Java, 1755-1825," Indonesia, no. 37, pp. 1-47, 1984.

[31] M. C. Ricklefs, "Some statistical evidence on Javanese social, economic and demographic history in the later seventeenth and eighteenth centuries," Mod. Asian Stud., vol. 20, no. 1, pp. 1-32, 1986.

[32] C. F. Emmons, "Hong Kong's feng shui: popular magic in a modern urban setting," $J$. Pop. Cult., vol. 26, no. 1, p. 39, 1992.

[33] L. Suryadinata, Pribumi Indonesians, the Chinese minority, and China: A study of perceptions and policies. Marshall Cavendish Intl, 2005.

[34] H. Kurniawan, "The Role of Chinese in Coming of Islam to Indonesia: Teaching Materials Development Based On Multiculturalism," Paramita Hist. Stud. J., vol. 27, no. 2, pp. 238-248, 2017.

[35] L. Suryadinata, Indonesia's foreign policy under Suharto: Aspiring to international leadership. Marshall Cavendish International, 1996.

[36] C. A. Coppel, "Revisiting Furnivall's 'plural society': Colonial Java as a mestizo society?," Ethn. Racial Stud., vol. 20, no. 3, pp. 562-579, 1997. 